Session 2526

\title{
Adaptation Of The Learning Factory Model For Implementation In A Manufacturing Laboratory
}

\author{
Mukasa E. Ssemakula and Gene Y. Liao \\ Division of Engineering Technology, Wayne State University, Detroit, MI 48202.
}

\begin{abstract}
The Learning Factory concept was first developed as part of the TRP/NSF funded Manufacturing Engineering Education Partnership (MEEP). The objective of the Learning Factory (LF) is to integrate a practice-based engineering curriculum that balances analytical and theoretical knowledge with physical facilities for product realization in an industrial-like setting $^{1,2}$. The LF model emphasizes practical experience and consequently, Engineering Technology (ET) and other programs that emphasize hands-on experiences for students are well suited to implementing the LF model. This paper describes a project whose goal is to adapt the LF model for implementation in regular academic programs oriented to practical applications without having to build an actual factory.
\end{abstract}

This work is being accomplished by modifying five carefully selected courses in our programs, leading to the use of coordinated projects across those courses. The projects focus on the making of functional model engines. In the various courses, students will generate CAD drawings of all the engine components, produce process plans for and make those components, and assemble and test the engines. This will afford students a good understanding and experience of the full range of issues involved in product design, manufacturing planning, fabrication, assembly and testing of functional products. Because the project is based on modifying existing courses rather than developing new ones, we expect the results of the project to be easily adaptable to a wide range of programs.

\section{Introduction}

The high cost of setting up a state-of-the-art manufacturing facility means that universities usually have to make difficult choices about the resources they dedicate to courses in manufacturing. Consequently, many university courses in Manufacturing Processes or related subjects are skewed towards theoretical concepts and offer limited hands-on experience for the students (if any). Frequently, students' exposure to actual processes is limited to observing demonstrations by the instructor, or simply through video tapes, but with the students not getting their hands on the equipment. There is also the possibility of using simulations but these are still primarily in the research stage and they do not yet offer sufficient realism ${ }^{3}$. 
Another way to overcome these constraints is to arrange for cooperative experiences that allow students to work in a manufacturing facility as part of their degree program ${ }^{4,5}$. This requires extra commitment from the students, since it normally entails at least one semester away from school. Moreover, it can be challenging to find appropriate placements for all students participating in the program.

\section{An Adaptation of the Learning Factory Model}

The Learning Factory concept was first developed as part of the TRP/NSF funded Manufacturing Engineering Education Partnership (MEEP). The concept was implemented at each of the three originating schools as a $3500 \mathrm{ft}^{2}$ facility at Penn State, a $4000 \mathrm{ft}^{2}$ facility at University of Puerto Rico, and a $6500 \mathrm{ft}^{2}$ facility at University of Washington. The objective of the Learning Factory is to integrate a practice-based engineering curriculum that balances analytical and theoretical knowledge with physical facilities for product realization in an industrial-like setting. The LF model offers:

(1) A practice-based engineering curriculum which balances analytical and theoretical knowledge with manufacturing, design, business realities, and professional skills;

(2) Learning Factories at each partner institution, integrally coupled to the curriculum, for hands-on experience in design, manufacturing, and product realization;

(3) Strong collaboration with industry;

(4) Outreach to other academic institutions, government and industry.

The LF model offers students in traditional engineering disciplines an alternative path to a degree that directly prepares them for careers in manufacturing, design and product realization. This project's goal is to adapt the LF model for implementation in ET programs. The Learning Factory model has been quite successful and is in the process of being implemented in the engineering curricula of a number of other universities, including University of MissouriColumbia, and Marquette University ${ }^{6}$. The goal of the project described here is to adapt and implement of the Learning Factory model in the Engineering Technology (ET) programs at Wayne State Univerisity, and subsequently disseminate the results to other ET programs around the country. The five courses detailed in Table 1 were targeted for this implementation.

Table 1: Brief Descriptions of Targeted Courses

\begin{tabular}{|l|l|}
\hline Course & Description \\
\hline ET2140 Computer Graphics & $\begin{array}{l}\text { Solution of drafting problems and development of } \\
\text { graphic presentations using CAD techniques }\end{array}$ \\
\hline MIT3510 Manufacturing Processes & $\begin{array}{l}\text { Study of manufacturing processes like machining, } \\
\text { welding and forming; Fabrication of materials using } \\
\text { conventional machines; Calibration and setup }\end{array}$ \\
\hline MIT3600 Process Engineering & $\begin{array}{l}\text { Manufacturing analysis. Selection of parameters, } \\
\text { tooling and equipment. Process planning. }\end{array}$ \\
\hline $\begin{array}{l}\text { MIT4700 Computer Aided Design } \\
\text { \& Manufacturing }\end{array}$ & $\begin{array}{l}\text { Fundamentals of computer-aided manufacturing. } \\
\text { CNC, 2 and 3-d applications programming }\end{array}$ \\
\hline ET4999 Senior Project & Students design, build and test a functional product. \\
\hline
\end{tabular}


ET2140 and ET4999 are required in all six degree programs we offer. MIT3510 is required in four of the programs, and available as an elective in the other two. MIT4700 is required in this project's core programs of MIT and PDT, and is available as an elective in the other four. MIT3600 is an elective open to all programs. These courses impact a large number of students and this justifies their choice as the basis of the proposed adaptation. The targeted courses will be revamped around the unifying theme of the design, fabrication, assembly and test of a model engine. Our implementation differs from the original model in the following ways:

1. With regard to design, our students will focus more on computer aided drafting rather than conceptual design or functional analysis. This is appropriate for an engineering technology program as opposed to the regular engineering programs in which the Learning Factory model originated.

2. Activities in all courses will be centered around selected model engines (one per semester). This retains the realism of producing a functional product while using less expensive yet robust machines. Although a change in focus from the model Learning Factory, it is appropriate for the targeted student body.

3. The working student population we serve provides inherent collaboration with industry. This is reflected in many of the projects student undertake in their ET4999 Senior Project course. Upgrading our laboratories will allow students to undertake more of those real life projects.

4. Because our programs are already practice, all activities will be integrated into existing courses, no new courses or programs will be developed. This will make the results of the project readily acceptable in the ET community.

The new activities being introduced are shown in Table 2. The course MIT3510 will serve as the springboard of this adaptation because, as detailed in section 3, we already have experience in implementing some of the concepts underlying the Learning Factory in that course. Each of the targeted courses incorporates hands-on experiences in the form of laboratories or projects. This project will coordinate these experiences.

Table 2: Overview of Proposed Course Activities

\begin{tabular}{|l|l|}
\hline Course & Proposed Activities \\
\hline $\begin{array}{l}\text { ET2140 } \\
\text { Computer Graphics }\end{array}$ & $\begin{array}{l}\text { Generate fully dimensioned CAD drawings of select engine components } \\
\text { and assembly drawings of complete model engine, including bill of } \\
\text { materials. }\end{array}$ \\
\hline $\begin{array}{l}\text { MIT3510 } \\
\text { Pronufacturing }\end{array}$ & $\begin{array}{l}\text { Make the engine components using conventional machine tools. } \\
\text { Instructor will give informal guidance on planning issues. Assemble and } \\
\text { test engine. Write detailed report describing the manufacturing and } \\
\text { assembly process. }\end{array}$ \\
\hline $\begin{array}{l}\text { MIT3600 } \\
\text { Process } \\
\text { Engineering }\end{array}$ & $\begin{array}{l}\text { Generate formal process plans for fabricating the engine components, } \\
\text { including determination of all machining parameters. Also generate the } \\
\text { assembly plan. }\end{array}$ \\
\hline $\begin{array}{l}\text { MIT4700 Computer } \\
\text { Aided Design \& } \\
\text { Manufacturing }\end{array}$ & $\begin{array}{l}\text { Based on MIT 3600 process plans, develop NC programs to make } \\
\text { engine components. Verify and troubleshoot NC programs. Produce } \\
\text { engine components on NC machines. Assemble and test engine. Write } \\
\text { detailed report describing the manufacture and assembly processes. }\end{array}$ \\
\hline
\end{tabular}

Proceedings of the 2003 American Society for Engineering Education Annual Conference \& Exposition Copyright (0) 2003, American Society for Engineering Education. 
Ideally, students would use the CAD drawings they have generated in ET2140 in subsequent courses and use the process plans they developed in MIT3600 in MIT4700. This type of continuity is difficult to achieve in a commuter school with many students taking only one or two courses a semester. To get around this problem, we will have the results generated from one course flow into a subsequent course the next semester even if not all students follow those results.

\section{Prototype Course}

We have developed a course in Manufacturing Processes (MIT 3510), that covers a wide range of processes, while still affording the students an opportunity to gain substantial practical experience with selected processes ${ }^{7}$. The course requires five contact hours a week, divided into two 2.5 hours sessions per week over a complete semester. One session is for lectures while the other session is spent in the laboratory. The course is worth 3 semester credits. The course's topical coverage includes such traditional processes as casting, forming, machining, and welding; plus unconventional processes such as electromechanical and electro-spark machining.

It is generally not feasible for any university to develop laboratories encompassing all of the different processes covered in a course like this. A choice has to be made as to the processes that will be supported. In our case, we have a manufacturing laboratory that supports the traditional machining processes such as turning, milling, grinding and welding. Prior to the changes described here, the time available in the laboratory was used to make several small parts such as the one shown in Figure 1. These introduced the traditional processes like milling and drilling.

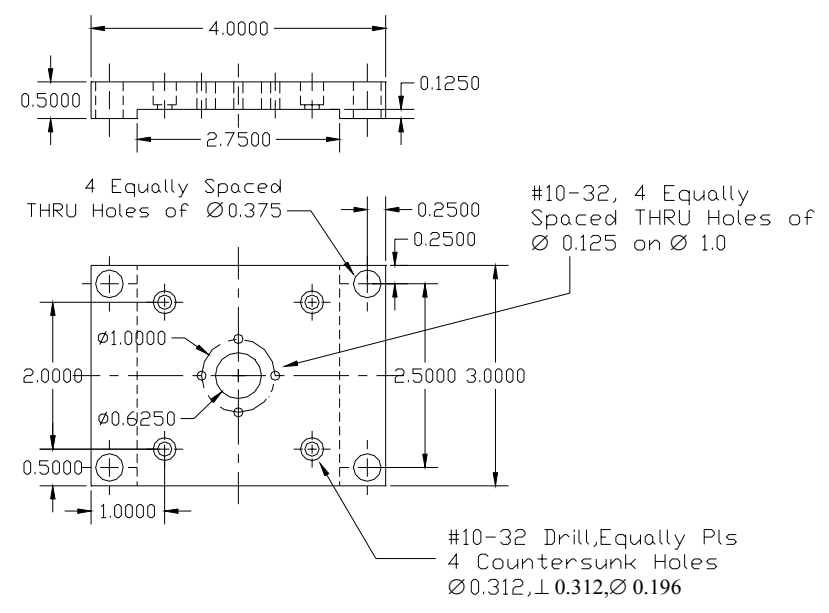

FIGURE 1

INTRODUCTORY MILL PROJECT

Whereas the students were able to gain experience with the processes using this approach, there was a sense that more could be done to make the labs both more challenging and interesting for the students. To accomplish this, we decided to change the nature of the projects that students have to do in the laboratory. Specifically, we moved away from the series of simplistic, unrelated and non-functional components and decided to incorporate a major project instead. The project we settled on was the making of a model engine that students could test at 
the end of the semester. Using a major project of this nature offers many advantages to the students. Not only do they get exposed to the same processes they encountered in the original setting, but now they also get to assemble the engine they make and watch it in operation. This approach is similar to that described by Weller et al ${ }^{8}$.

Having a functional product at the end of the semester is inherently motivating to the students and affords them a sense of accomplishment that is extremely satisfying to both the instructor and the students. In our case, we have drawings for several different model engines to chose from which has allowed us to vary the specific model that is made from semester to semester.

Because making a model engine is quite a challenging project, we have retained two of the simpler components that students used to make before we changed our approach. One component is used to familiarize students with the operation of a lathe, while the other is used to familiarize them with the operation of a mill and drill-press. The students work on these simple projects before embarking on the making of the engine. Figure 1 shows the component we use to introduce milling type processes. An outline of the rest of the laboratory projects that we use is given below. The progression through components of varying difficulty is clearly evident.

\section{Course Outline: Laboratories}

Shop Practices: This introductory session introduces students to the manufacturing laboratory environment and acquaints them with general shop practices and safety procedures. (1 week)

Lathe 1: This project introduces students to the use of a cutoff-saw, grinding of cutting tools, and the basic machining processes used on a lathe. See Figure 2. (3 weeks)

Mill 1: This project introduces students to the basic machining processes used on a milling type machine. (3 weeks)

Major Project: The Model Engine: For this project, students making a complete model engine in line with the requirements given on standard shop drawings. This requires the use of both a lathe and a milling machine. See Figure 3. (6 weeks)

Weld 1: This exercise introduces students to the basic arc welding processes. (1 week)

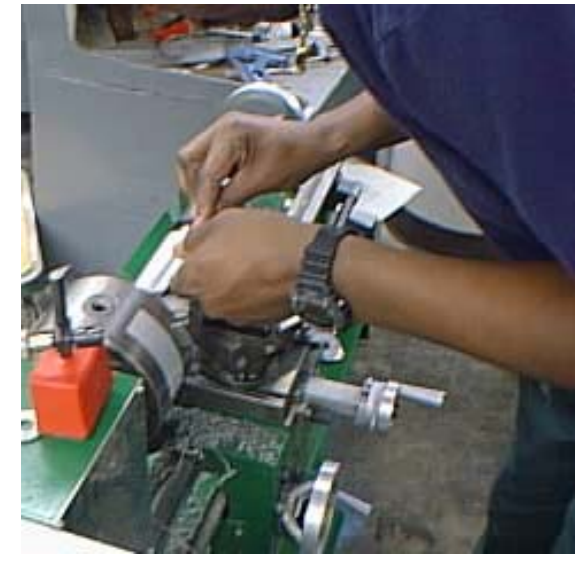

FIGURE 2

IN-PROCESS GAUGING OF A TURNED COMPONENT

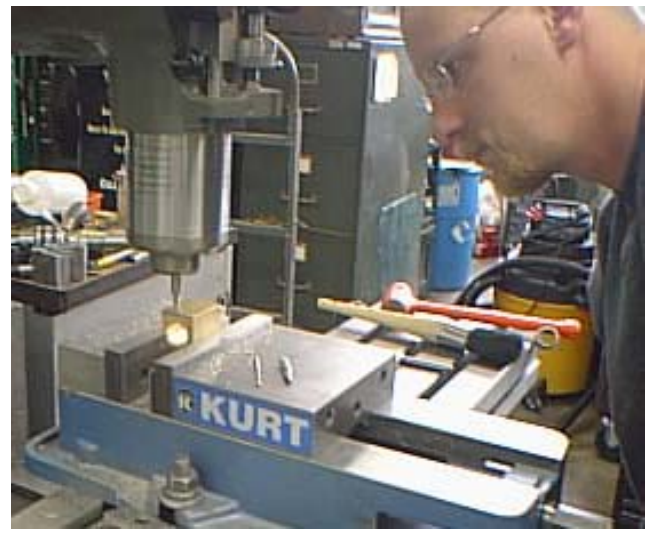

FIGURE 3

MiLLING AN ENGINE COMPONENT 
In addition to gaining hands-on experience, this course is also used to develop students' skills in written communication which is one of the ABET accreditation requirements. To accomplish this, students are required to write a detailed laboratory report for each of the projects they undertake. The same basic outline is followed for all projects. For the model engine project however, additional instructions are given. These call for the inclusion of a complete bill of materials, identification of processed parts and a description of how they are made, clearly distinguishing them from off- the-shelf items such as screws; and a description of the engine assembly and testing procedure. In grading the laboratory work, the quality of parts made as well as the written report are taken into account.

The experience we have had with this course has been very positive and students have also reacted very favorably to the new approach. In particular, seeing their model engines in operation is a thrill to the students. The only problem has been with how to decide who gets to keep the finished product since there was one engine between 3-4 students. Figure 4 shows an example of one of the engines made by the students.

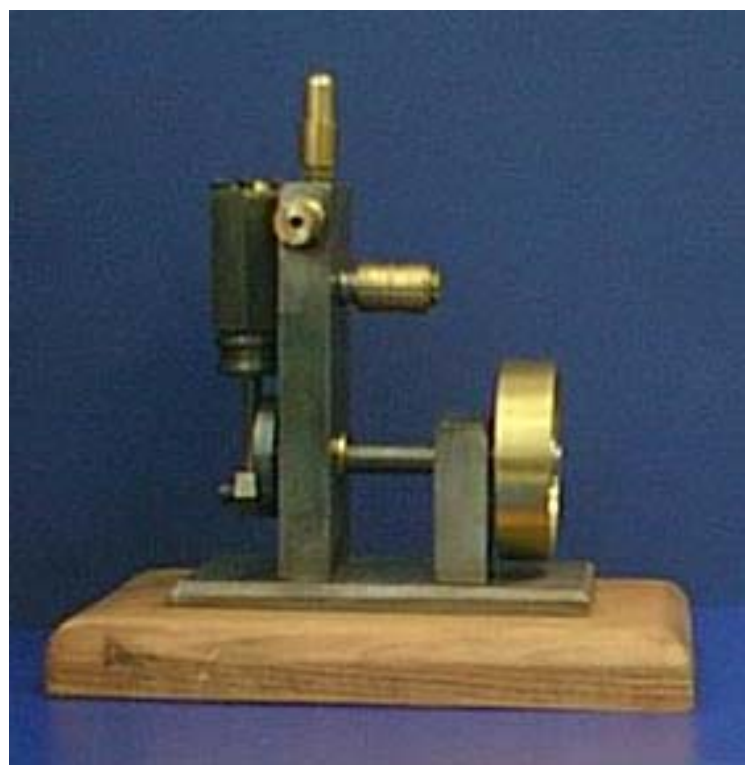

FIGURE 4

A Finished 'PIP-SQUEEK' MODEL ENGINE

\section{Conclusion}

The approach described in this paper uses challenging team-based laboratory projects coordinated across selected courses to help students gain hands-on experience in the design, manufacturing planning, fabrication, assembly and testing of functional products. The projects start with simple components and progress to the manufacture and assembly of fully operational model engines. The projects also expose students to the idea of working in teams, a skill that is highly sought by industry. The work is still ongoing but initial student reaction has been quite enthusiastic. 


\section{References}

1. Lamancusa, John S. et al: "The Learning Factory - A New Approach to Integrating Design and Manufacturing into Engineering Curricula." Proceedings, 1995 Annual Conference of ASEE, June 25-28, 1995; Anaheim, CA. pp. $2262-2269$.

2. DeMeter, Edward C., Jorgensen, Jens E. and Rullan, Augustine: "The Learning Factory of The Manufacturing Engineering Education Program." Proceedings, SME International Conference on Manufacturing Education for the 21st Century, San Diego, CA. March 1996.

3. National Research Council: "Information Technology for Manufacturing: A Research Agenda." Washington DC, National Academy Press (1995).

4. Denton, D.D.: "Engineering Education for the $21^{\text {st }}$ Century: Challenges and Opportunities," Journal of Engineering Education, January 1998, pp. 19-22.

5. Ram, B., Sarin, S., Park, E. and Mintz, P.: "Providing Manufacturing Experiences to Industrial Engineering Students through an Extension Program." Proceedings, $29^{\text {th }}$ ASEE/IEEE Frontiers in Education Conference, Nov. 10 -13, 1999, San Juan, Puerto Rico.

6. Domblesky, Joseph and Cariapa, Vikram: Adapting a Learning Factory Model to Re-Engineer Manufacturing Curricula. http://www.eng.mu.edu/domblesk/CCLI\%20Project/projectsummary.html

7. Ssemakula, M.E.: 'Introducing Hands-on Manufacturing Experience to Students', Proceedings, ASEE Annual Conference \& Exposition, June 16-19, 2002; Montréal, Quebec Canada.

8. Weller, J.E., Kumar, V., Grove, S. and Bordia, R.K.: "The Development of a Project-Based Introduction to Manufacturing Laboratory Involving a Stirling Engine." Proceedings, Annual Conference of the ASEE http://www.asee.org/conferences/search/00131.PDF

\section{Biographical Sketch}

MUKASA E. SSEMAKULA graduated from the University of Manchester Institute of Science and Technology, UK, with a Ph.D. in Mechanical Engineering in 1984. He joined the Wayne State University in 1993 and is currently teaching courses in Manufacturing/Industrial Engineering Technology. His has research interests and has published widely in the areas of Manufacturing Systems and Computer Aided/Distance Education.

GENE Y. LIAO received his BSME from National Central University, Taiwan; MSME from the University of Texas, Mechanical Engineer from Columbia University, and the Doctor of Engineering degree from the University of Michigan. His scholarly interests are in mechanical design, multibody dynamics, and CAE applications in manufacturing. He had 15 years of experience in the automotive sector prior to joining the Wayne State faculty. 